\title{
Extensive extramammary Paget's disease of the vulva involving the bladder postradical split skin graft reconstruction
}

\author{
Angela Mujukian, ${ }^{\circledR}$ Anni Innamaa, Jonathan Lippiatt, Louise Melson
}

Division of Oncologic

Gynaecology, Department of Obstetrics \& Gynaecology, Poole Hospital NHS Foundation Trust, Poole, Dorset, UK

\section{Correspondence to}

Dr Angela Mujukian, amujukian@gmail.com

Accepted 1 February 2019

\section{DESCRIPTION}

An 84-year-old woman presented to the gynaecology department with a 9-month history of vulval soreness, irritation and bleeding. Her medical history included Dukes C sigmoid adenocarcinoma, thyroid malignancy and multiple medical comorbidities including atrial fibrillation and ischaemic heart disease. The patient was a heavy smoker. On pelvic examination, there was a large erythematous plaque affecting the right labia majora, and biopsies (figure 1) confirmed vulval extramammary Paget's disease (EMPD). Topical Imiquimod (TLR-7 inhibitor) was initially started with minimal response. The patient then underwent a wide local excision and had several local recurrences excised over the next few years. Finally, the patient required radical excision with a split skin graft reconstruction 6 years after original diagnosis. Three months following the radical procedure, the patient complained of vulval pain, haematuria and urethral spasm. Cystoscopy of the bladder revealed a trabeculated mucosa with a $1 \mathrm{~cm}$ raised pale lesion. The lesion was biopsied and confirmed to show recurrent vulval EMPD with disease extension involving Paget's cells in the urethra (figure 2) and base of the bladder. Following urology review, a decision was made that in view of the patient's performane status and in keeping with her wishes she was not eligibile for advanced treatment options such as radiotherapy. She was therefore referred to palliative and pain services for best supportive care.

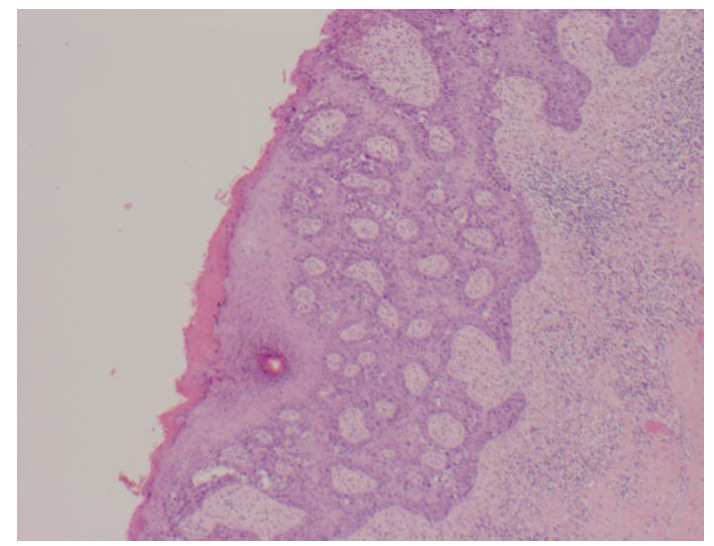

Figure 1 Vulval Paget's $x 10$ magnification. Biopsy on $H \& E$ stain of the vulva shows a section of the skin is in keeping with typical Paget's cells with clearly demarcated abundant pale cytoplasm containing mucin, scattered within the epidermis.

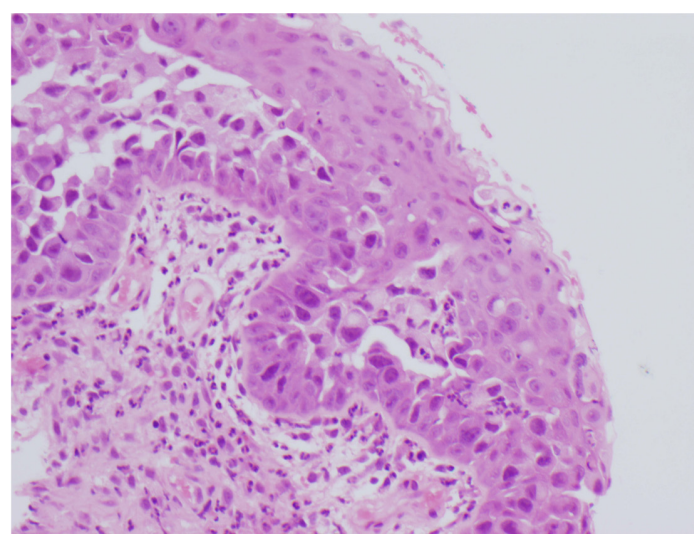

Figure 2 Urethral Paget's x40 magnification. Biopsy on H\&E stain of the urethra shows a section of the urethral squamous mucosa with Paget's cells and pagetoid involvement of the urethral mucosa in keeping with vulval extramammary Paget's disease with extension involving the bladder and urethra.

EMPD was first described by Sir James Paget in $1874,{ }^{1}$ and the first case of EMPD of the vulva was reported in $1901 .^{2}$ EMPD of the vulva is a rare intraepithelial adenocarcinoma-in-situ originating in the apocrine sweat glands with Paget's cells found in sites other than the skin of the breast such as the genital regions (labia majora, scrotum, and perianal skin). The most frequently associated carcinomas are apocrine. Vulval EMPD most commonly occurs in postmenopausal women in their 50s and clinically presents with pruritus and soreness. The lesion typically presents as a pink eczematous-like lesion with white islands of hyperkeratosis and/or red, flaky, weeping patches. ${ }^{3-6}$ Patients may also be asymptomatic or present with pain, bleeding and chronic itching after several unsuccessful attempts of moisturisers and topical steroid creams with minimal response. Diagnosis is made by skin biopsy and or immunohistochemistry staining of GCDFP15, CK-7, CK-20 and CEA. Pathologically, EMPD of the vulva resembles mammary Paget's of the nipple and areola. ${ }^{78}$

Other factors associated with EMPD of the vulva include caucasian race, genetic predisposition, previous radiation exposure, increased body mass index and history of hormone replacement therapy. $^{9}$

Patients with EMPD of the vulva are at increased risk of synchronous or metachronous neoplasms including cervical, colorectal, and transitional epithelium carcinomas. $^{7} 810$ Therefore, routine 
screening in some cases and prolonged surveillance has been recommended, although there are no clear guidelines. Recommended screening tests to rule out co-existing malignancies include, colonoscopy, cervical cytology, mammogram, cystoscopy, and/or urinary cytology to rule out coexisting or underlying malignancies. ${ }^{7-10}$

Differential diagnoses of vulval EMPD includes psoriasis, linchen simplex chronicus/sclerosus/planus, differentiated vulval intraepithelial neoplasia, squamous cell carcinoma, histiocytosis, condylomata acuminata and melanoma. ${ }^{11}$

Prognosis is favourable if the lesion is localised to epidermis but poor with invasion to dermis. First line treatment includes vulvectomy and/or wide local excision with wide margins up to $1.5-2 \mathrm{~cm}$ away from visible lesion.

Recurrence rate after surgical excision is reportedly $32 \%{ }^{12}$ and up to $50 \%-70 \%$ of lesionswill have positive resection margins. ${ }^{7913}$ Paget's has also been treated with Imiquimod cream or Cidofovir, radiotherapy, laser and photodynamic therapy in isolated cases. A small percentage (10\%-20\%) carry an underlying malignancy. Primary origin is skin and secondary adjacent regions may extend from the urethra, cervix, bladder, ${ }^{4}{ }^{14-17}$ breast and bowel.

An option for treatment in this case would have been to proceed with surgery, but this would have involved an extensive resection with cystourethrectomy, and ileal conduits. Radiotherapy is sometimes treatment of choice in cases of postsurgical recurrence. Combination treatment with inclusion of chemotherapy has shown no clear benefit. Outcomes with wide local excision pose significantly longer survival rates versus radical interventions. ${ }^{49}$ Yet, alternative therapies such as medical management of Imiquimod remain unclear and controversial as some studies showed a positive clinical response with recurrent EMPD of the vulva. ${ }^{718}$

Recently, a specific urothelial marker, GATA-3, classified as highly sensitive and specific for urothelial and breast carcinomas failed to differentiate between primary vulval Paget's disease from pagetoid urothelial intraepithelial neoplasia. ${ }^{19}$

\section{Learning points}

- Primary treatment for Paget's disease of the vulva remains surgery, though alternative therapies exist and the optimal management currently remains unclear. ${ }^{6718}$

- Patients with extramammary Paget's disease (EMPD) of the vulva are at increased risk of concomitant or metachronous neoplasms and routine screening and surveillance (colonoscopy, cervical cytology, mammography and cystoscopy) should be considered. ${ }^{6-10}$

- EMPD of the vulva is difficult to treat for surgeons as majority of patients will have multiple recurrences. ${ }^{712}$
Contributors AM: Conception/design/acquisition data/interpretation data/original drafting and revision of manuscript/responsible for accuracy and integrity of work. Al: Patient care/conception/design/ manuscript revisions/final approval/accountable for all aspects of work. JL: Patient care/conception/design/ manuscript revisions/final approval/accountable for all aspects of work. LM: Patient care/conception/design/ manuscript revisions/final approval/accountable for all aspects of work.

Funding The authors have not declared a specific grant for this research from any funding agency in the public, commercial or not-for-profit sectors.

Competing interests None declared.

Patient consent for publication Next of kin consent obtained.

Provenance and peer review Not commissioned; externally peer reviewed.

\section{REFERENCES}

1 Paget JS. Disease of Mammary Areola Preceding Cancer of the Mammary Gland, 1874:87-9.

2 Dubreuilh W. Paget's disease of the vulva. Br J Dermatol 1901;13:407-13.

3. British Association of Dermatologists BAD Guidelines. The information standard: extramammary paget's disease: patient information leaflet. Produced November 2016 http://www.bad.org.uk/for-the-public/patient-information-leaflets/extramammarypagets-disease/?showmore=1\&returnlink=http $\% 3 a \% 2 f \% 2 f w w w . b a d . o r g . u k \% 2 f f o r-$ the-public\%2fpatient-information-leaflets\#.XGGguC3MwnU.

4 Parker LP, Parker JR, Bodurka-Bevers D, et al. Paget's disease of the vulva: pathology, pattern of involvement, and prognosis. Gynecol Oncol 2000;77:183-9.

5 Black D, Tornos C, Soslow RA, et al. The outcomes of patients with positive margins after excision for intraepithelial Paget's disease of the vulva. Gynecol Oncol 2007; 104:547-50.

6 Mendivil AA, Abaid L, Epstein HD, et al. Paget's disease of the vulva: a clinicopathologic institutional review. Int J Clin Oncol 2012;17-569-74.

7 Onaiwu CO, Salcedo MP, Pessini SA, et al. Paget's disease of the vulva: A review of 89 cases. Gynecol Oncol Rep 2017;19:46-9.

8 Preti M, Micheletti L, Ghiringhello B, et al. [Vulvar paget's disease. Clinico-pathologic review of the literature]. Minerva Ginecol 2000;52:203-11.

9 Onaiwu CO, Ramirez PT, Kamat A, et al. Invasive extramammary Paget's disease of the bladder diagnosed 18years after noninvasive extramammary Paget's disease of the vulva. Gynecol Oncol Case Rep 2014;8:27-9.

10 Feuer GA, Shevchuk M, Calanog A. Vulvar Paget's disease: the need to exclude an invasive lesion. Gynecol Oncol 1990;38:81-9.

11 van der Linden M, Meeuwis KA, Bulten J, et al. Paget disease of the vulva. Crit Rev Oncol Hematol 2016;101:60-74

12 Shaco-Levy R, Bean SM, Vollmer RT, et al. Paget disease of the vulva: a histologic study of 56 cases correlating pathologic features and disease course. Int J Gynecol Pathol 2010;29-69-78

13 Tebes S, Cardosi R, Hoffman M, et al. Paget's disease of the vulva. Am J Obstet Gynecol 2002;187-281-4.

14 Kay JM, Southwood WF. Paget's disease of the vulva associated with an unusual bladder tumour. Br J Cancer 1964;18:233-7.

15 Powell FC, Bjornsson J, Doyle JA, et al. Genital Paget's disease and urinary tract malignancy. J Am Acad Dermatol 1985;13:84-90.

16 Kuroda J, Takemura T, Kanokogi M. [A case of Paget's disease of the vulva with bladder metastasis]. Hinyokika Kiyo 1987;33:774-8.

17 Inoue S, Shiina $H$, Igawa $M$, et al. Paget's disease of the vulva with bladder invasion: a case report. Arch Gynecol Obstet 2012;285-1493-6.

18 Cowan RA, Black DR, Hoang LN, et al. A pilot study of topical imiquimod therapy for the treatment of recurrent extramammary Paget's disease. Gynecol Oncol 2016;142:139-43.

19 Morbeck D, Tregnago AC, Netto GB, et al. GATA3 Expression in Primary Vulvar Paget Disease: A potential Pitfall Leading to Misdiagnosis of Pagetoid Urthothelial Neoplasia.

Copyright 2019 BMJ Publishing Group. All rights reserved. For permission to reuse any of this content visit

https://www.bmj.com/company/products-services/rights-and-licensing/permissions/

BMJ Case Report Fellows may re-use this article for personal use and teaching without any further permission.

Become a Fellow of BMJ Case Reports today and you can:

- Submit as many cases as you like

- Enjoy fast sympathetic peer review and rapid publication of accepted articles

- Access all the published articles

- Re-use any of the published material for personal use and teaching without further permission

For information on Institutional Fellowships contact consortiasales@bmjgroup.com

Visit casereports.bmj.com for more articles like this and to become a Fellow 